\title{
Widespread demographic explosion of a non-indigenous hydrozoan on an oceanic island
}

\author{
Fernando Espino ${ }^{1}$, Francisco J. Otero-Ferrer ${ }^{1}$, Néstor E. Bosch ${ }^{2}$, Josep Coca ${ }^{3}$, \\ Ricardo Haroun ${ }^{1}$, Fernando Tuya ${ }^{1}$ \\ ${ }^{1}$ Grupo de Investigación en Biodiversidad y Conservación, IU-ECOAQUA, Universidad de Las Palmas de Gran Canaria, \\ Crta. Taliarte s/n, 35214 Telde, Canary Islands, Spain. \\ (FE) (Corresponding author) E-mail: fesprod @ gobiernodecanarias.org. ORCID-iD: https://orcid.org/0000-0003-3988-7297 \\ (FJO-F) E-mail: fran.otero@ fpct.ulpgc.es. ORCID-iD: https://orcid.org/0000-0002-1328-9662 \\ (RH) E-mail: ricardo.haroun@ulpgc.es. ORCID-iD: https://orcid.org/0000-0003-1348-692X \\ (FT) E-mail: ftuya@yahoo.es. ORCID-iD: https://orcid.org/0000-0001-8316-5887 \\ ${ }^{2}$ School of Biological Sciences, UWA Oceans Institute, Crawley (Perth), WA, Australia. \\ (NEB) E-mail: nbosch1989@ gmail.com. ORCID-iD: https://orcid.org/0000-0003-0421-8456 \\ ${ }^{3}$ Departamento de Biología, Facultad de Ciencias del Mar, Universidad de Las Palmas de Gran Canaria, Canary Islands, \\ Spain. \\ (JC) E-Mail: jcoca@ pesca.gi.ulpgc.es. ORCID-iD: https://orcid.org/0000-0003-0625-8240
}

\begin{abstract}
Summary: The arrival of non-indigenous species into new areas is one of the main processes altering the oceans globally. Macrorhynchia philippina is a large-sized colonial hydrozoan of an invasive nature. To obtain a deeper understanding of the process of colonization of new areas, it is essential to describe the ecological pattern through scales of temporal and spatial variation. In this study, we describe the colonization by M. philippina of an oceanic island (Gran Canaria Island, Canary Islands, eastern Atlantic). We describe the abundance and size structure patterns of M. philippina in three nearshore habitats, rocky reefs, seagrass meadows and rhodolith seabeds, at times before (2014), during (2016) and after (2017) the demographic explosion of this species. On rocky reefs and rhodolith seabeds, the abundance of colonies increased dramatically in 2017 relative to 2014 , e.g. from 0 to 138 colonies $/ 100 \mathrm{~m}^{2}$. On seagrass meadows, however, the colonies were smaller. In summary, $M$. philippina shows an ecological plasticity to rapidly colonize different types of nearshore habitats, but with varying success.
\end{abstract}

Keywords: non-indigenous species; hydrozoan; colonization; nearshore habitats; Canary Islands.

\section{Explosión demográfica de un hidrozoo exótico en una isla oceánica}

Resumen: La aparición de especies exóticas es uno de los principales factores que alteran los océanos de forma global. Macrorhynchia philippina es un hidrozoo colonial de tamaño grande y naturaleza invasora. Para tener un mejor conocimiento del proceso de colonización es fundamental describir los patrones ecológicos a escalas de variación temporal y espacial. En este estudio, describimos el proceso de colonización por M. philippina en una isla oceánica (Gran Canaria, Islas Canarias, Atlántico oriental). Se describen los patrones de abundancia y estructura de tallas de M. philippina en tres hábitats costeros: arrecifes rocosos, praderas de fanerógamas marinas y fondos de rodolitos, antes (2014), durante (2016) y después (2017) de la explosión demográfica de la especie. Sobre arrecifes rocosos y en fondos de rodolitos, la abundancia de las colonias se incrementó drásticamente en 2017 con relación a 2014, e.g. desde 0 hasta 138 colonias/100 m²; este incremento fue menor en las praderas de fanerógamas marinas. En las praderas marinas, la longitud de las colonias fue más pequeña que sobre arrecifes rocosos y fondos de rodolitos. Consecuentemente, la colonización rápida por $M$. philippina demuestra su plasticidad ecológica para colonizar diferentes tipos de hábitats costeros, aunque con diferente éxito.

Palabras clave: especie exótica; hidrozoo; colonización; hábitats costeros; Islas Canarias.

Citation/Como citar este artículo: Espino F., Otero-Ferrer F.J., Bosch N.E., Coca J., Haroun R., Tuya F. 2020. Widespread demographic explosion of a non-indigenous hydrozoan on an oceanic island. Sci. Mar. 84(2): 111-118. https://doi. org/10.3989/scimar.04949.09A

Editor: E. Cebrián.

Received: May 7, 2019. Accepted: February 4, 2020. Published: March 24, 2020.

Copyright: ( $) 2020$ CSIC. This is an open-access article distributed under the terms of the Creative Commons Attribution 4.0 International (CC BY 4.0) License. 


\section{INTRODUCTION}

Translocation of marine species is one of the main processes altering the oceans globally (Ruiz et al. 1997, 1999, Geburzi and McCarthy 2018). Certain human activities favour the artificial dispersal of marine species. In particular, maritime traffic is the main dispersal vector of species outside their native ranges, involving $\mathrm{ca}$. 93161 vessels yearly (Molnar et al. 2008, UNCTAD 2017). In a single day, ca. 10000 marine species are transported in the ballast waters, or as a part of the "biofouling" attached to hulls, across the world's oceans (Carlton 1999, de Castro et al. 2017). The translocation of species underpins the concept of introduced species or non-indigenous species (NIS), i.e. species transported by humans, accidentally or deliberately, outside their natural distribution ranges, even across biogeographical barriers (Thomsen et al. 2015).

Most introduced species fail in their initial attempt to settle in new habitats; some NIS can adapt to new conditions, but fail to proliferate and alter recipient native communities (Geburzi and McCarthy 2018). A small group, however, can severely impact native biodiversity and communities, and have flow-on social and economic effects on fisheries, aquaculture and tourism (European Commission 2014, Thomsen et al. 2015); these are considered invasive species. Typically, invasive species have large reproduction, growth, dispersal and colonization rates. Some of them can be even considered "ecosystem engineers" because of the large physical and biological implications of their presence (Cuddington and Hastings 2004). In general, invasive species are a major threat to local biodiversity and a serious environmental concern for the conservation of the oceans, altering the functions and services delivered by local ecosystems (Bax et al. 2003, Thomsen et al. 2010, 2015).

In the scientific literature, there is growing evidence of the number of invasive species, covering a broad range of taxonomic lineages and affecting almost all eco-regions of the world (Thomsen et al. 2015). Within the phylum Cnidaria, only a small number of potential invasive hydroids (class Hydrozoa) have been described (González-Duarte et al. 2016a). This is the case of Pennaria disticha Goldfuss, 1820 in Hawaii (Miglietta et al. 2015), Turritopsis dohrnii (Weismann, 1883), considered as a global invader (Miglietta and Lessios 2009), Maeotias marginata (Modeer, 1791) in the Baltic Sea (Väinölä and Oulasvirta 2001), Moerisia lyonsi (Boulenger, 1908) in North America (Ma and Purcell 2005), and Blackfordia virginica Mayer, 1910. The last species is found in estuarine zones of all oceans (Mills and Sommer 1995, Haydar 2012), exerting a high predation pressure on planktonic crustaceans and fish eggs, with effects on commercial fish populations (González-Duarte et al. 2016a). Similarly, Clytia hummelincki (Leloup, 1935) is invasive in the Mediterranean, preying on eggs and fish larvae (GonzálezDuarte et al. 2016b). Importantly, the arrival and establishment of many NIS species into new locations has been typically described from just one nearshore habitat, e.g. of 327 non-native marine and estuarine species reported in North America, $46 \%$ were reported only on hard substrata, and $22 \%$ occurred on both hard substrata and soft sediments (Ruiz et al. 2009).

Macrorhynchia philippina Kirchenpauer, 1872 (Hydrozoa, Alglaopheniidae) has a circumglobal distribution in tropical, subtropical and temperate waters of the planet (Ansín Agís et al. 2001, Watson 2002). In the last few years, the species has reached new areas, particularly at temperate latitudes, facilitated by its high dispersal capacity (Çinar et al. 2006, Morri et al. 2009) and by global warming (Gravili et al. 2013). In some places, e.g. the eastern Mediterranean, the species is considered invasive (Çinar et al. 2006, Zenetos et al. 2010). In the eastern Atlantic, it was initially recorded at Cape Verde Islands (Ritchie 1908) and on the coasts of Guinea Bissau (Billard 1931). It was later found in the archipelagos of Madeira and Selvagens (Bianchi et al. 1998, Ansín Agís et al. 2001, Wirtz 2007). Molecular analyses further suggested that the species was introduced through shipping, either in the ballast waters or attached to ship hulls (Moura et al. 2012). In the Canary Islands, the species was first recorded by Riera et al. (2016).

M. philippina is a large-sized (20-30 $\mathrm{cm}$ in height) colonial hydrozoan, which can become locally abundant under favourable environmental conditions (Moura et al. 2012). Colonies have a bushy appearance, resulting from the irregular ramification of the main branches arising from a central, dark-brown, axis (Fig. 1). From the main branches, fine ramifications support rows of white polyps. The colonies are very stinging and could be harmful to humans due to the presence of large nematocysts $(100 \mu \mathrm{m}$ in length, Marques et al. 2002); indeed, this species has been given the common name "stinging hydroid". The increase in abundance of this species could reduce tourism activities and have a negative impact on local economies (Çinar et al. 2006, González-Duarte et al. 2016a).

Most works on NIS merely report the presence of these species outside their native ranges of occurrence (Ruiz et al. 1999). For many marine NIS, the mode of introduction, establishment success across habitats and impacts on marine ecosystems remain largely unknown (Streftaris et al. 2005, Ojaveer et al. 2015). In this context, to obtain a deeper understating of potential invasions, it is necessary to describe the ecological pattern, e.g. abundance and size structure patterns across scales of temporal and spatial variation (Byers et al. 2002, Streftaris et al. 2005). In this study, to the best of our knowledge we describe, for the first time, the process of colonization of an oceanic island by M. philippina. We describe the abundance and size structure patterns of the species on three nearshore habitats (rocky reefs, seagrass meadows and rhodolith seabeds) before, during and after its demographic explosion.

\section{MATERIALS AND METHODS}

\section{Study region}

The Canary Islands are an oceanic archipelago of volcanic origin located in the eastern Atlantic Ocean 


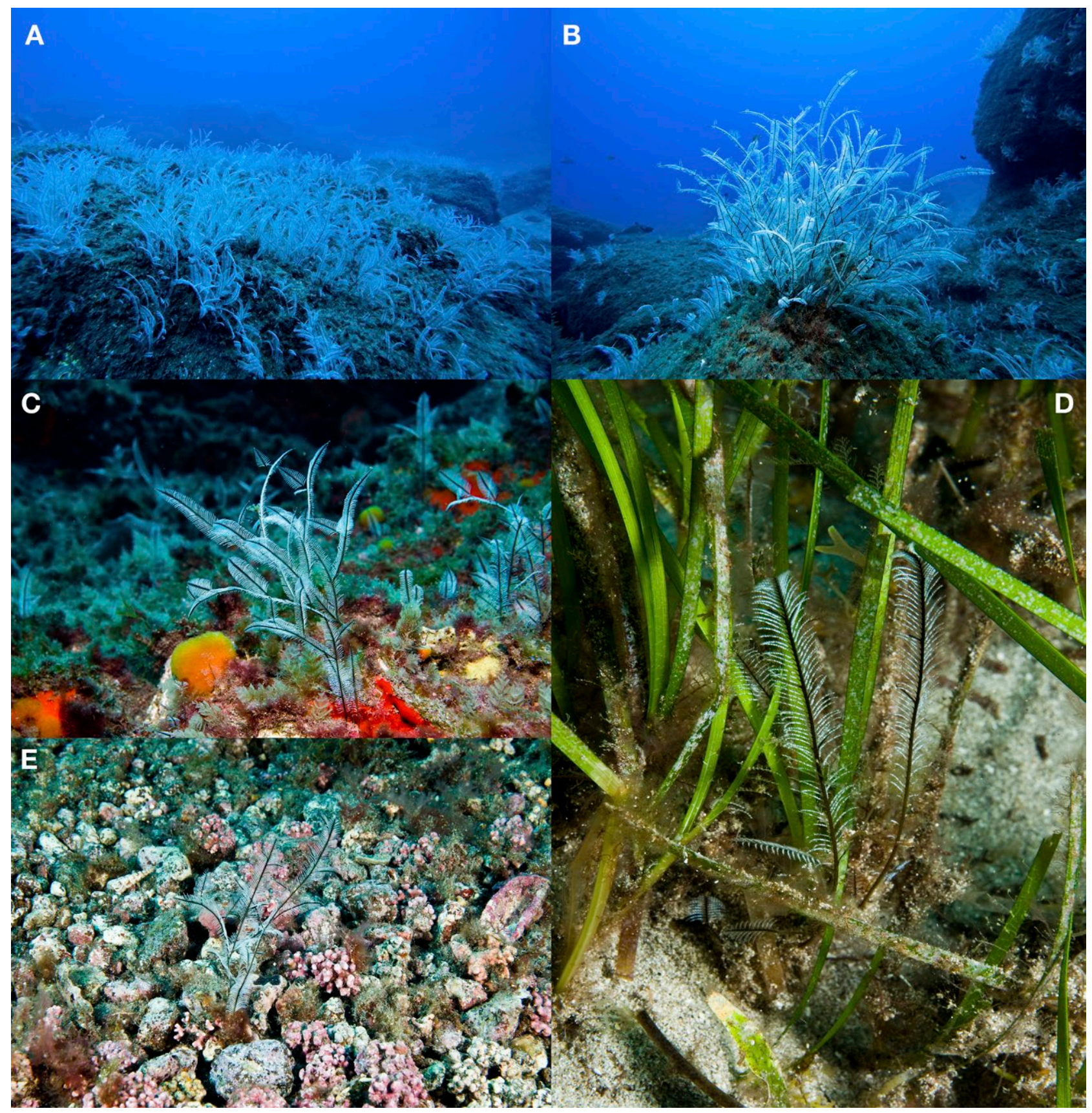

Fig. 1. - Colonies of M. philippina on different types of habitats, including (A and B) rocky reefs, (C) a rocky bottom with Aplidium proliferum (Chordata) and Crisularia gracilis (Bryozoa), (D) the edge of a seagrass meadow and (E) rhodolith nodules.

$\left(27.68-29.58^{\circ} \mathrm{N} ; 18.28-14.58^{\circ} \mathrm{W}\right)$. Each island arose from an independent volcanic system except the easternmost islands, Fuerteventura and Lanzarote, which have the same insular platform. Therefore, large depths are found between adjacent islands. The Canary Current and the African Upwelling System have strong influences on the oceanographic patterns of the Canarian Archipelago (Tuya et al. 2004, 2006, VélezBelchí et al. 2015). In Gran Canaria Island, sea water temperatures typically change from $18^{\circ} \mathrm{C}$ in winter to $23^{\circ} \mathrm{C}$ in summer (Navarro-Pérez and Barton 2001). In the last few decades, however, the sea surface temperature time series has shown a significant trend of linear increase over time (Fig. 2, p<0.01, Espino et al. 2019), including a yearly Sen slope of $0.021^{\circ} \mathrm{C} \mathrm{y}^{-1}$, similarly reported for the Canary Current Large Marine Ecosystem (Vélez-Belchí et al. 2015).

\section{Sampling strategy}

We here took advantage of the monitoring plan of nearshore habitats (i.e. rocky reefs, macroalgal beds, rhodolith seabeds and seagrass meadows) in Gran Canaria Island by the IU-ECOAQUA to describe the demographic explosion of $M$. philippina. Three sites between 5 and $25 \mathrm{~m}$ depth were selected for each of three habitats: rocky reefs, rhodolith seabeds and seagrass meadows (Table 1). At each of the nine sites, 


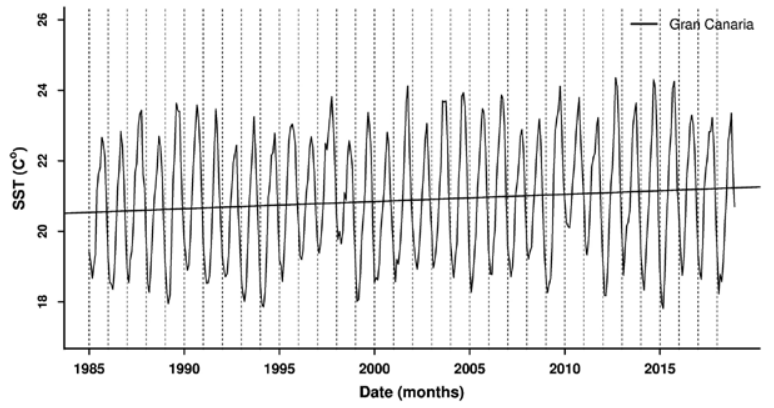

Fig. 2. - Patterns in sea surface water temperatures (SST) from January 1985 to December 2018 at the island of Gran Canaria. The data (monthly L4 product code 010_001) were compiled by the marine segment of the Copernicus European system (www.marine.copernicus.eu). Monthly data files were requested using the command line sub-setting and downloading tools, including the corresponding linear trend.

the abundance and size structure of the colonies were sampled before, during and after the demographic explosion (summer of 2014, 2016 and 2017).

\section{Abundance and size of colonies}

Five $100 \mathrm{~m}^{2}$ transects ( $25 \mathrm{~m}$ long $\times 4 \mathrm{~m}$ wide) were deployed at each site and time. A SCUBA diver then annotated the number of colonies per transect and the size (main axis) of each colony with a ruler (to the nearest $\mathrm{cm}$ ). The size was only measured in 2017 , when the species had been successfully established in Gran Canaria. A three-way ANOVA tested whether abundances differed between habitats, sites within habitats and years. Both 'Habitat' and 'Year' were considered fixed factors, whereas 'Sites' was a random source of variation nested within habitats. The data were $\ln (\mathrm{x}+1)$-transformed to stabilize variances; the Levene test was used to check for homoscedasticity. Pairwise SNK tests were used to resolve differences between levels of fixed factors; in particular, pairwise tests resolved significance of differ-

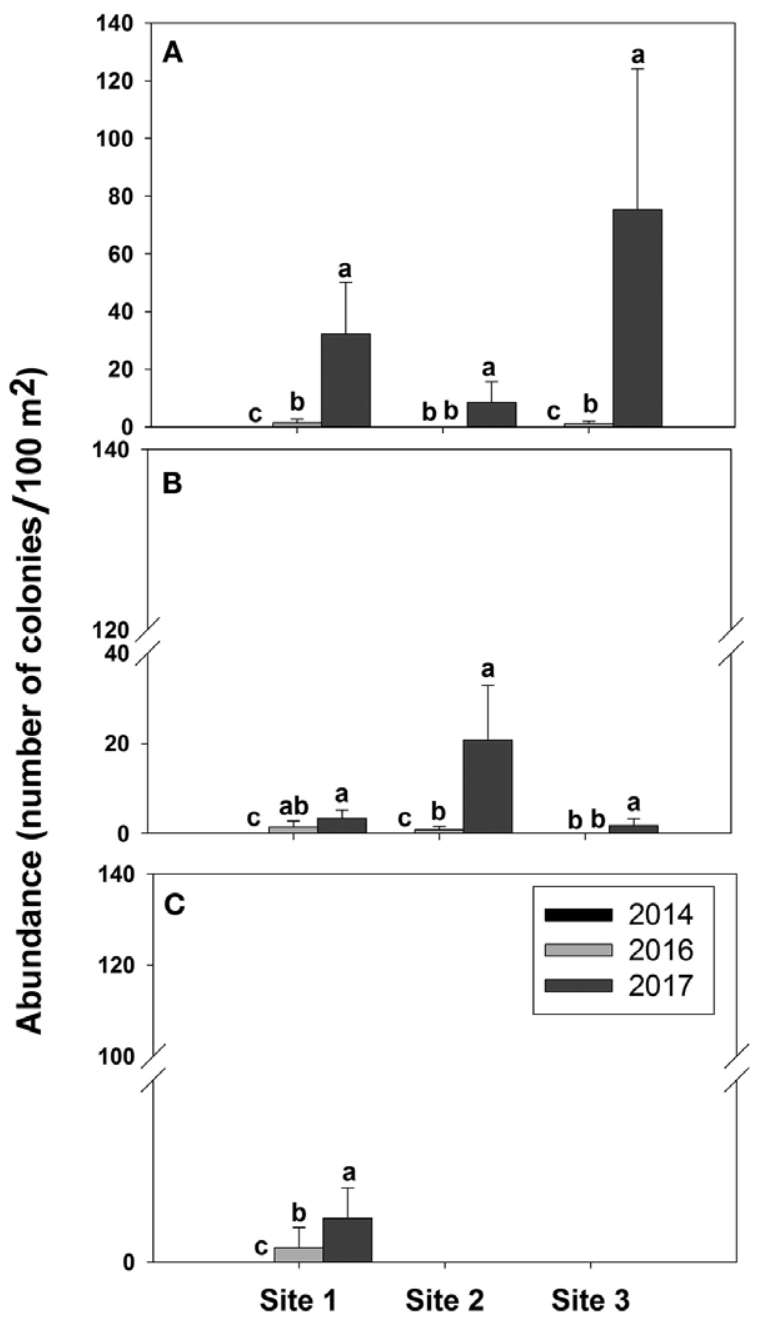

Fig. 3. - Mean abundances (+SE) of colonies at each of three sites on (A) rocky reefs, (B) rhodolith seabeds and (C) seagrass meadows at times before (2014), during (2016) and after (2017) the arrival of the species. Different letters above bars denote statistically significant differences in abundance for each site between years.

Table 1. - Location and depth of the sampling sites at Gran Canaria Island.

\begin{tabular}{|c|c|c|c|}
\hline Site name $\left(\mathrm{n}^{\circ}\right)$ & Habitat & Geographic coordinates & Depth $(\mathrm{m})$ \\
\hline Taliarte (1) & rocky reef & $27^{\circ} 59^{\prime} 18.9^{\prime \prime} \mathrm{N} 15^{\circ} 22^{\prime} 12.25^{\prime \prime} \mathrm{W}$ & $5-7$ \\
\hline Tufia (2) & rocky reef & $27^{\circ} 57^{\prime} 50.45^{\prime \prime} \mathrm{N} 15^{\circ} 22^{\prime} 41.17^{\prime \prime} \mathrm{W}$ & $10-15$ \\
\hline El Cabrón (3) & rocky reef & $27^{\circ} 52^{\prime} 21.95^{\prime \prime} \mathrm{N} 15^{\circ} 22^{\prime} 52.66^{\prime \prime} \mathrm{W}$ & $12-15$ \\
\hline Gando North (1) & rhodolith seabed & $27^{\circ} 56^{\prime} 41.28^{\prime \prime} \mathrm{N} 15^{\circ} 21^{\prime} 30.85^{\prime \prime} \mathrm{W}$ & $20-25$ \\
\hline Gando Shipwreck (2) & rhodolith seabed & $27^{\circ} 55^{\prime} 54^{\prime \prime} \mathrm{N} 15^{\circ} 21^{\prime} 11^{\prime \prime} \mathrm{W}$ & 25 \\
\hline Gando South (3) & rhodolith seabed & $27^{\circ} 55^{\prime} 18.21^{\prime \prime} \mathrm{N} 15^{\circ} 21^{\prime} 49.20^{\prime \prime} \mathrm{W}$ & $20-25$ \\
\hline Arinaga Bay (1) & seagrass meadow & $27^{\circ} 51^{\prime} 04.49^{\prime \prime} \mathrm{N} 15^{\circ} 23^{\prime} 37.41^{\prime \prime} \mathrm{W}$ & $10-12$ \\
\hline Gando Bay (2) & seagrass meadow & $27^{\circ} 55^{\prime} 31.47^{\prime \prime} \mathrm{N} 15^{\circ} 22^{\prime} 47.7^{\prime \prime} \mathrm{W}$ & 10 \\
\hline Juncalillo (3) & seagrass meadow & $27^{\circ} 47^{\prime} 16.1^{\prime \prime} \mathrm{N} 15^{\circ} 29^{\prime} 44.36^{\prime \prime} \mathrm{W}$ & $5-7$ \\
\hline
\end{tabular}

Table 2. - Results of three-way ANOVA testing the effects of habitat (a fixed factor), year (a fixed factor) and site (a random factor nested within habitat) on the abundance of colonies of M. philippina at Gran Canaria Island. Pairwise tests for the significant habitat $\times$ year interaction are included.

\begin{tabular}{lcccc}
\hline Source & DF & MS & F & \\
\hline Habitat & 2 & 135.835 & 5.58 & 0.0427 \\
Site (habitat) & 6 & 24.326 & 16.73 & 34.64 \\
Year & 2 & 386.301 & 8.44 & 7.67 \\
Habitat $\times$ year & 4 & 94.120 & 11.151 & 0.000001 \\
Year $\times$ site (habitat) & 12 & 1.454 & 0.00001 \\
Residual & 108 & 2014: Reefs $=$ Rhodolith seabeds = Seagrass meadows & \\
Pairwise tests & 2016: Reefs = Rhodolith seabeds > Seagrass meadows & & \\
& 2017: Reefs $>$ Rhodolith seabeds > Seagrass meadows & & \\
\hline
\end{tabular}



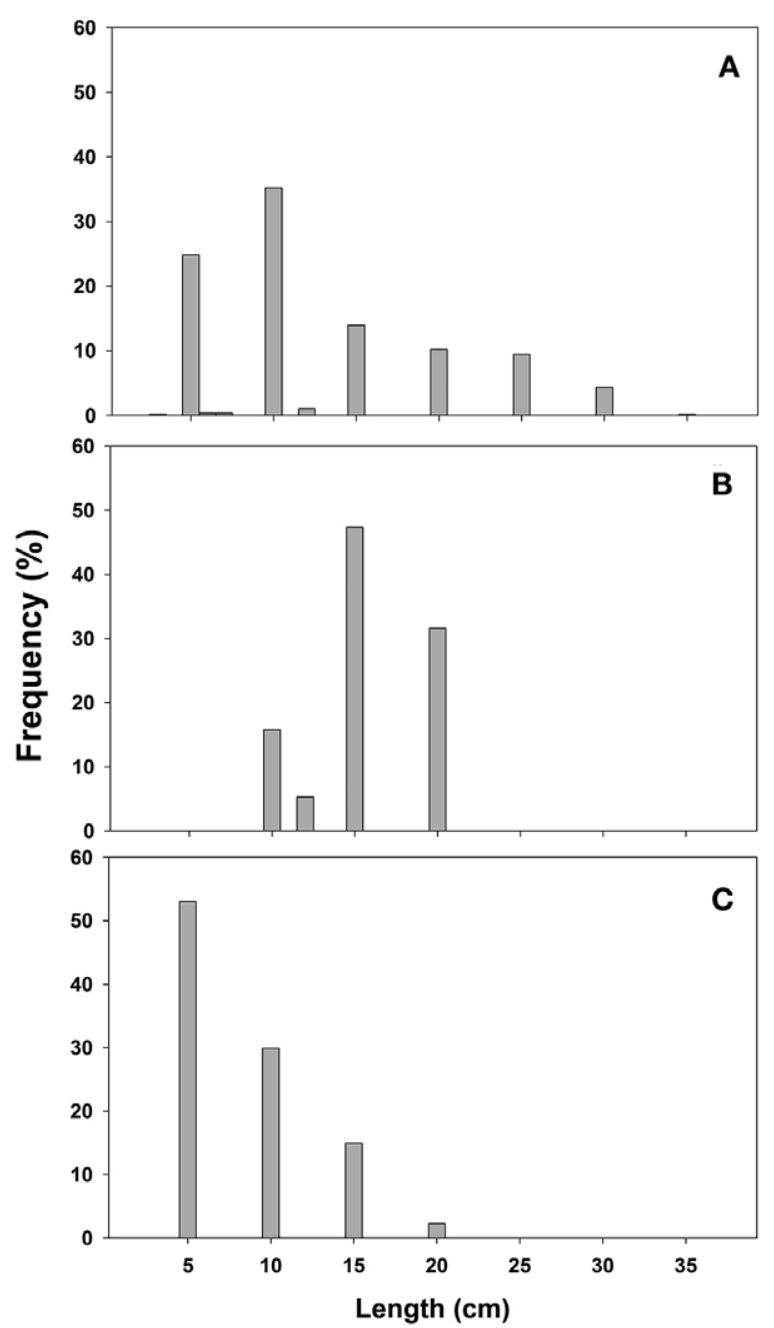

Fig. 4. - Size frequency distribution of the total length of colonies on $(\mathrm{A})$ rocky reefs, $(\mathrm{B})$ rhodolith seabeds and $(\mathrm{C})$ seagrass meadows after the arrival (2017).

ences in abundances for each site between years. Size structure data (pooling data from all sites from each habitat) were analysed through a contingency table; a chi-square tested whether the size structure of colonies differed between the three habitats.

\section{RESULTS}

On both rocky reefs and rhodolith seabeds, abundances increased dramatically in 2017 in comparison with 2014, but the increase was lower in seagrass meadows ('Habitat $\times$ Year', $\mathrm{p}=0.0018$, pairwise tests, Table 2, Fig. 3). Overall, abundances were greater (from 0 to a maximum of 138 colonies $/ 100 \mathrm{~m}^{2}$ ) in 2017 than in 2016 and 2014 ('Year', $p=0.000001$, Table 2). Within each habitat, we detected large inter-site variation in the abundance of colonies ('Site(Habitat)', p=0.000001, Table 2, Fig. 3), i.e. abundances were greater at certain sites. The size structure of colonies varied between habitats $\left(\chi^{2}=158.17, \mathrm{df}=18, \mathrm{p}<2.2 \mathrm{e}-16\right)$. On seagrass meadows, the colonies were smaller than on reefs and rhodolith seabeds (Fig. 4).

\section{DISCUSSION}

This work has demonstrated that Macrorhynchia philippina underwent a widespread demographic explosion in Gran Canaria Island after the first sighting in 2015 (Riera et al. 2016). The colonies were identified near ( $<10$ nautical miles) two industrial ports on Gran Canaria Island (industrial ports of Las Palmas and Arinaga). Most likely, the species arrived as biofouling attached to ship hulls (Riera et al. 2016). A similar pattern has also been observed at Tenerife Island, where colonies were observed near two industrial ports (Santa Cruz de Tenerife and Granadilla) (A. Brito and L. Moro, pers. com.). Fouling species can be easily dispersed by maritime traffic (Ferreira et al. 2006), and oil rigs in particular can transport a wide range of biological assemblages (Wanless et al. 2010). The arrival of NIS at the Canary Islands has increased dramatically since 2011, when the traffic of oil rigs and digging vessels rose, particularly at Gran Canaria and Tenerife Islands. Certain NIS that are considered invasive have been recorded since then, including the corals Oculina patagonica and Tubastraea coccinea (Brito et al. 2017) and the portunid crab Cronius ruber (González et al. 2017). Similarly, the observation of dozens of tropical fish species in the vicinity of industrial ports in Gran Canaria, particularly around the industrial port of Las Palmas, has been linked to the maritime routes of oil rigs (Brito et al. 2011, Triay-Portella et al. 2015, Pajuelo et al. 2016). The progressive warming of waters around Gran Canaria Island in the last few decades may have also facilitated the successful colonization of this hydroid, which has an affinity for warmth (Gravili et al. 2013).

In just two years, the hydroid underwent a rapid expansion, colonizing large areas of the east coast of Gran Canaria Island. Importantly, the species has been identified in a range of habitats (rocky reefs, rhodolith seabeds and seagrass meadows; this study), as well as artificial structures (shipwrecks and fishing traps; Riera et al. 2016). On some reefs, there has been a massive increase, i.e. from 0 to 138 colonies $/ 100 \mathrm{~m}^{2}$. This pattern is common during the initial phases of invasion by invasive NIS (Thomsen et al. 2015), i.e. introduction-lag time-expansion (Geburzi and McCarthy 2018). Such invasion success suggests that $M$. philippina has a large colonization potential and ecological plasticity, i.e. the species was found in varying habitat types. In addition to a large dispersal capacity, this species displays a high investment in growth of somatic tissues and a high competition capacity for space (González-Duarte et al. 2016a). Considered a 'broadcast spawner', this hydroid has a complex life cycle. Colonies are hermaphroditic, and male and female medusoids are released by gonozoids inhabiting the same colony (Bourmaud and Gravier-Bonnet 2004). Overall, after fertilization, the hydrozoan planula larvae settle in less than $24 \mathrm{~h}$, suggesting low dispersal capacities over distances of no more than a few kilometres (Calder 1993, Postaire et al. 2017). However, this seems to be sufficient to colonize wide areas at small oceanic islands such as Gran Canaria Island. 
In this study, we detected between-habitat differences in the degree of establishment of colonies. Larger abundances were observed in rocky reefs and rhodolith seabeds than in seagrass meadows. The main ecological drivers affecting the biology of hydroids are the substrate type, light, hydrodynamics, salinity, sedimentation, temperature, food availability and pollution (Boero 1984, Gili and Hughes 1995). Benthic colonies are attached to either natural or artificial hard bottoms; the stability of the substrate is key for the attachment, growth and survival of colonies. The greater stability provided by rocky bottoms explains the greater abundance of colonies on reefs. Rhodoliths, however, can be sporadically overturned during strong currents or stormy episodes (Marrack 1999, Basso et al. 2009, Vale et al. 2018); this may help to explain the comparatively lower abundance of colonies there. Finally, seagrass meadows are very unstable, because there is a lack of hard structures, so colonies were only found attached to shells, isolated pebbles or unburied seagrass rhizomes (pers. obs.). In addition, the continuous movement of seagrass canopies and sand may hinder the settlement of larvae. In turn, only a few species of hydrozoans inhabit soft bottoms (Gili and Hughes 1995).

Water movement is a key element affecting the size of the colonies of hydroids. As they are passive filter-feeders, there is a trade-off between sufficient surge for the delivery of food and strong flows detaching the colonies from the substrate (Gili and Hughes 1995). According to these authors, the size of colonies tends to decrease with increasing surge intensity. In our study, smaller colonies were observed on rhodolith seabeds than on rocky reefs. The former habitat, in the study area, is under the influence of strong tidal currents (Otero-Ferrer et al. 2019), which fits the observation of Gili and Hughes (1995). On the other hand, in the study area, seagrass meadows are always located in semi-enclosed areas protected from strong currents and swells (Fabbri et al. 2015). A comparatively lower intensity of water flows most likely supplies a lower amount of food resources for the colonies of the hydroid, which could explain the smaller size of colonies in this habitat than on the reefs and rhodolith seabeds.

Invasive NIS tend to affect recipient assemblages (Carlton 2009). The effects of the invader can be classified as positive (e.g. habitat creation, increased species richness, provision of food) or negative (e.g. competition, habitat destruction, decreased species richness) (Thomsen et al. 2015). This study, however, has not analysed potential effects on native marine flora and fauna; at present, we cannot speculate on potential ecological implications.

In summary, this study has described the colonization process of a colonial hydroid at an oceanic island. The successful establishment of $M$. philippina demonstrates its great ecological plasticity. Continuous monitoring of coastal habitats is necessary to address the implications of the arrival of invasive species such as this hydroid in the study region. Urgent environmental policies to prevent, track and mitigate the arrival of NIS is required in this regard, particularly in the context of intense traffic of oil rigs and drill ships in the study region.

\section{ACKNOWLEDGEMENTS}

The authors thank Tony Sanchez for his help during the field sampling. Thanks to Manuel M. González Duarte who provided valuable information on hydrozoans. This work was partially financed by the Excellence International Campus of the Canary Islands (CEI-Canarias), the Agency for Research, Innovation and Information Society of the Canary Islands and the EcoAqua European project (ERA CHAIR programme - Grant Agreement no. 621341).

\section{REFERENCES}

Ansín Agís J., Ramil F., Vervoort W. 2001. Atlantic Leptolida (Hydrozoa, Cnidaria) of the families Aglaopheniidae, Halopterididae, Kirchenpaueriidae and Plumulariidae collected during CANCAP and Mauritania-II expeditions of the National Museum of Natural History, Leiden, the Netherlands. Zool. Verh. Leiden 333: 1-268.

Basso D., Nalin R., Nelson C.S. 2009. Shallow-water Sporolithon rhodoliths from north island (New Zealand). Palaios 24: 92-103. https://doi.org/10.2110/palo.2008.p08-048r

Bax N., Williamson A., Aguero M., et al. 2003. Marine invasive alien species: a threat to global biodiversity. Mar. Pol. 27: 313-323. https://doi.org/10.1016/S0308-597X(03)00041-1

Bianchi C.N., Morri C., Sartoni G., et al. 1998. Sublittoral epibenthic communities around Funchal (Ilha da Madeira, NE Atlantic). Bol. Mus. Munic. Funchal 5: 59-80.

Billard A. 1931. Hydroïdes de l'expédition du "Sylvana". Bull. Mus. Natl. His. Nat. 3: 248-250.

Boero F. 1984. The ecology of marine hydroids and effects of environmental factors: A review. Mar. Ecol. 5: 93-118. https://doi.org/10.1111/j.1439-0485.1984.tb00310.x

Bourmaud C., Gravier-Bonnet N. 2004. Medusoid release and spawning of Macrorhynchia philippina Kirchenpauer, 1872 (Cnidaria, Hydrozoa, Aglaopheniidae). Hydrobiologia 530531: 365-372. https://doi.org/10.1007/s10750-004-2665-5

Brito A., Clemente S., Herrera R. 2011. On the occurrence of the African hind, Cephalopholis taeniops, in the Canary Islands (eastern subtropical Atlantic): introduction of large-sized demersal littoral fishes in ballast water of oil platforms? Biol. Invasions 13: 2185-2189. https://doi.org/10.1007/s10530-011-0049-0

Brito A., López C., Ocaña O., et al. 2017. Colonización y expansión en Canarias de dos corales potencialmente invasores introducidos por las plataformas petrolíferas. Vieraea 45: 65-82. https://doi.org/10.31939/vieraea.2017.45.04

Byers J.E., Reichard S., Randall J.M., et al. 2002. Directing research to reduce the impacts of nonindigenous species. Conserv. Biol. 16: 630-640. https://doi.org/10.1046/j.1523-1739.2002.01057.x

Calder D.R. 1993. Local distribution and biogeography of the hydroids (Cnidaria) of Bermuda. Caribbean J. Sci. 29: 61-74.

Carlton J.T. 1999. Molluscan Invasions in Marine and Estuarine Communities. Malacologia 41: 439-454.

Carlton J.T. 2009. Deep invasion ecology and the assembly of communities in historical time. In: Rilov G., Crooks J.A. (eds), Biological invasions in marine ecosystems. Springer, Berlin, pp. $13-56$ https://doi.org/10.1007/978-3-540-79236-9_2

Çinar M.E., Bilecenoglu M., Öztürk B., et al. 2006. New records of alien species on the Levantine coast of Turkey. Aquat. Invasions 1: 84-90. https://doi.org/10.3391/ai.2006.1.2.6

Cuddington K., Hastings A. 2004. Invasive engineers. Ecol. Model. 178: 335-347. https://doi.org/10.1016/j.ecolmodel.2004.03.010

de Castro M.C.T., Fileman T.W., Hall-Spencer J.M. 2017. Invasive species in the Northeastern and Southwestern Atlantic Ocean: A review. Mar. Pollut. Bull. 116: 41-47. https://doi.org/10.1016/j.marpolbul.2016.12.048

Espino F., Tuya F., del Rosario A., et al. 2019. Geographical range extension of the Spotfin burrfish, Chilomycterus reticulatus (L. 
1758), in the Canary Islands: A reponse to ocean warming? Diversity 11: 230 https://doi.org/10.3390/d11120230

European Commission. 2014. Regulation (EU) No 1143/2014 of the European Parliament and of the Council of 22 October 2014 on the prevention and management of the introduction and spread of invasive alien species. Off. J. Eur. Union L317: 35-55.

Fabbri F., Espino F., Herrera R., et al. 2015. Trends of the seagrass Cymodocea nodosa (Magnoliophyta) in the Canary Islands: population changes in the last two decades. Sci. Mar. 79: 7-13. https://doi.org/10.3989/scimar.04165.19B

Ferreira C.E.L., Gonçales J.E.A., Coutinho R. 2006. Ship hulls and oil platforms as potential vectors to marine species introduction. J. Coast. Res. 39: 1341-1346.

Geburzi J.C., McCarthy M.L. 2018. How do they do it? - Understanding the success of marine invasive species. In: Jungblut S., Liebich V., Bode M. (eds), YOUMARES 8 - Oceans Across Boundaries: Learning from each other. Springer, Switzerland, pp. 109-124. https://doi.org/10.1007/978-3-319-93284-2_8

Gili J.-M., Hughes R.G. 1995. The ecology of marine benthic hydroids. Oceanogr. Mar. Biol. Annu. Rev. 33: 351-426.

González J.A., Triay-Portella R., Escribano A., et al. 2017. Northernmost record of the pantropical portunid crab Cronius ruber in the eastern Atlantic (Canary Islands): natural range extension or human-mediated introduction? Sci. Mar. 81: 81-89. https://doi.org/10.3989/scimar.04551.17B

González-Duarte M.M., Megina C., López-González P.J., et al. 2016a. Cnidarian alien species in expansion. In: Goffredo S., Dubinsky Z. (eds), The Cnidaria, Past, Present and Future. Springer Int. Publ., Switzerland, pp. 139-160. https://doi.org/10.1007/978-3-319-31305-4 10

González-Duarte M.M., Megina C., De Vito D., et al. 2016b. An unified assessment of marine Mediterranean assemblages: a lesson from benthic hydroids. Mar. Ecol. 37: 155-163. https://doi.org/10.1111/maec.12271

Gravili C., Di Camillo C.G., Piraino S., et al. 2013. Hydrozoan species richness in the Mediterranean Sea: past and present. Mar. Ecol. 34: 41-62. https://doi.org/10.1111/maec.12023

Haydar D. 2012. What is natural? The scale of cryptogenesis in the North Atlantic. Ocean. Divers. Distrib. 18: 101-110. https://doi.org/10.1111/j.1472-4642.2011.00863x

Ma X., Purcell J.E. 2005. Effects of temperature, salinity, and predators on mortality of and colonization by the invasive hydrozoan Moerisia lyonsi. Mar. Biol. 147: 215-224. https://doi.org/10.1007/s00227-004-1538-9

Marques A.C., Junior V.H., Migotto A.E. 2002. Envenomation by a benthic Hydrozoa (Cnidaria): the case of Nemalecium lighti (Haleciidae). Toxicon 40: 213-215. https://doi.org/10.1016/S0041-0101(01)00196-9

Marrack E.C. 1999. The relationship between water motion and living rhodolith beds in the southwestern Gulf of California, Mexico. Palaios 14: 159-171. https://doi.org/10.2307/3515371

Miglietta M.P., Lessios H.A. 2009. A silent invasion. Biol. Invasions 11: 825-834. https://doi.org/10.1007/s10530-008-9296-0

Miglietta M.P., Odegard D., Faure B., et al. 2015. Barcoding techniques help tracking the evolutionary history of the introduced species Pennaria disticha (Hydrozoa Cnidaria). PloS ONE 10: e0144762. https://doi.org/10.1371/journal.pone.0144762

Mills C.E., Sommer F. 1995. Invertebrate introductions in marine habitats: two species of hydromedusae (Cnidaria) native to the Black Sea, Maeotias inexspectata and Blackfordia virginica, invade San Francisco Bay. Mar. Biol. 122: 279-288.

Molnar J.L., Gamboa R.L., Revenga C., et al. 2008. Assessing the global threat of invasive species to marine biodiversity. Front. Ecol. Environ. 6: 485-492. https://doi.org/10.1890/070064

Morri C., Puce S., Bianchi C.N., et al. 2009. Hydroids (Cnidaria: Hydrozoa) from the Levant Sea (mainly Lebanon), with emphasis on alien species. J. Mar. Biol. Assoc. U.K. 89: 49-62. https://doi.org/10.1017/S0025315408002749

Moura C.J., Cunha M.R., Porteiro F.M., et al. 2012. A molecular phylogenetic appraisal of the systematics of the Aglaopheniidae (Cnidaria: Hydrozoa, Leptothecata) from the north-east Atlantic and west Mediterranean. Zool. J. Linn. Soc. 164: 717-727. https://doi.org/10.1111/j.1096-3642.2011.00784.x
Navarro-Pérez E., Barton E.D. 2001. Seasonal and interannual variability of the Canary Current. Sci. Mar. 65: 205-213. https://doi.org/10.3989/scimar.2001.65s1205

Ojaveer H., Galil B.S., Campbell M.L., et al. 2015. Classification of Non-Indigenous Species on Their Impacts: Considerations for Application in Marine Management. PloS Biol. 13: e1002130. https://doi.org/10.1371/journal.pbio.1002130

Otero-Ferrer F., Mannarà E., Cosme M., et al. 2019. Early-faunal colonization patterns of discrete habitats units: A case study with rhodolith-associated vagile macrofauna. Estuar. Coast. Shelf Sci. 218: 9-22 https://doi.org/10.1016/j.ecss.2018.11.020

Pajuelo J.G., González J.A., Triay-Portella R., et al. 2016. Introduction of non-native marine fish species to the Canary Islands waters through oil platforms as vectors. J. Mar. Syst. 163: 23-30. https://doi.org/10.1016/j.jmarsys.2016.06.008

Postaire B., Gélin P., Bruggemann J.H., et al. 2017. One species for one island? Unexpected diversity and weak connectivity in a widely distributed tropical hydrozoan. Heredity 118: 385-394. https://doi.org/10.1038/hdy.2016.126

Riera R., Espino F., Moro L. 2016. Progressing the invasion of the hydrozoan Macrorhynchia philippina (Kirchenpauer, 1872) in the Atlantic archipelagos. Vieraea 44: 117-120.

Ritchie J. 1908. On collections of the Cape Verde Islands marine fauna, made by Cyril Crossland, M.A. (Cantab), B. Sc. (Lond.), F.Z.S., of St. Andrews University, July to September, 1904.The hydroids. Proc. Zool. Soc. Lond. 1907: 488-514. https://doi.org/10.1111/j.1469-7998.1907.tb06944.x

Ruiz G.M. Carlton J.T., Grosholz E.D. et al. 1997. Global invasions of marine and estuarine habitats by non-indigenous species: Mechanisms, extent, and consequences. Am. Zool. 37: 621-632. https://doi.org/10.1093/icb/37.6.621

Ruiz G.M., Fofonoff P., Hines A.H., et al. 1999. Non-indigenous species as stressors in estuarine and marine communities: Assessing invasion impacts and interactions. Limnol. Oceanogr. 44: $950-972$ https://doi.org/10.4319/1o.1999.44.3_part_2.0950

Ruiz G.M., Freestone A.L., Fofonoff P.W., et al. 2009. Habitat distribution and heterogeneity in marine invasion dynamics: the importance of hard substrate and artificial structure. In: Wahl M. (ed), Marine Hard Bottom Communities, Ecological Studies 206. Springer-Verlag, Berlin, Heidelberg, pp. 321-332. https://doi.org/10.1007/b76710_23

Streftaris N., Zenetos A., Papathanassiou E. 2005. Globalisation in marine ecosystems: The story of non-indigenous marine species across European seas. Oceanogr. Mar. Biol. Annu. Rev. 43: 419-453 https://doi.org/10.1201/9781420037449

Thomsen M.S. 2010. Experimental evidence for positive effects of invasive seaweed on native invertebrates via habitat-formation in a seagrass bed. Aquat. Invasions 5: 341-346. https://doi.org/10.3391/ai.2010.5.4.02

Thomsen M.S., Wernberg T., Schiel D. 2015. Invasions by nonindigenous species. In: Crowe T.P., Frid C.L.J. (eds), Marine Ecosystems: Human Impacts on Biodiversity, Functioning and Services. Cambridge Univ. Press, Cambridge, UK, pp. 274-331. https://doi.org/10.1017/CBO9781139794763.010

Triay-Portella R., Pajuelo J.G., Manent P., et al. 2015. New records of non-indigenous fishes (Perciformes and Tetraodontiformes) from the Canary Islands (north-eastern Atlantic). Cybium 39: $163-174$

Tuya F., Boyra A., Sánchez-Jérez P., et al. 2004. Relationships between rocky-reef fish assemblages, the sea urchin Diadema antillarum and macroalgae throughout the Canarian Archipelago. Mar. Ecol. Progr. Ser. 278: 157-169. https://doi.org/10.3354/meps278157

Tuya F., Ramírez R., Sánchez-Jérez P., et al. 2006. Coastal resources exploitation can mask bottom-up mesoscale regulation of intertidal populations. Hydrobiologia 553: 337-344. https://doi.org/10.1007/s10750-005-1246-6

United Nations Conference on Trade and Development (UNCTAD). 2017. Review of maritime transport. United Nations Publ., Geneva, 114 pp.

Väinölä R., Oulasvirta P. 2001. The first record of Maeotias marginata (Cnidaria, Hydrozoa) from the Baltic Sea: A Pontocaspian invader. Sarsia 86: 401-404. https://doi.org/10.1080/00364827.2001.10425527

Vale N.F., Amado-Filho G.M., Braga J.C., et al. 2018. Structure and composition of rhodoliths from the Amazon River mouth, 
118 - F. Espino et al.

Brazil. J. S. Am. Earth Sci. 84: 149-159.

https://doi.org/10.1016/j.jsames.2018.03.014

Vélez-Belchí P., González-Carballo M., Pérez-Hernández M.D., et al. 2015. Open ocean temperature and salinity trends in the Canary Current Large Marine Ecosystem. In: Valdés L., DénizGonzález I. (eds), Oceanographic and biological features in the Canary Current Large Marine Ecosystem. Tech. Ser., 115, IOCUNESCO, Paris. IOC, pp. 299-308.

Wanless R.M., Scott S., Sauer W.H.H., et al. 2010. Semi-submersible rigs: a vector transporting entire marine communities around the world. Biol. Invasions 12: 2573-2583.

https://doi.org/10.1007/s10530-009-9666-2
Watson J.E. 2002. Hydroids (Cnidaria: Hydrozoa) from Southern Queensland. Mem. Mus. Vic. 59: 337-354. https://doi.org/10.24199/j.mmv.2002.59.6

Wirtz P. 2007. On a collection of hydroids (Cnidaria, Hydrozoa) from the Madeira archipelago. Arquipel. Life Mar. Sci. 24: 11-16.

Zenetos A., Gofas S., Verlaque M., et al. 2010. Alien species in the Mediterranean Sea by 2010. A contribution to the application of European Union's marine Strategy Framework Directive (MSFD). Part I. Spatial distribution. Mediterr. Mar. Sci. 11: 381-493.

https://doi.org/10.12681/mms.87 